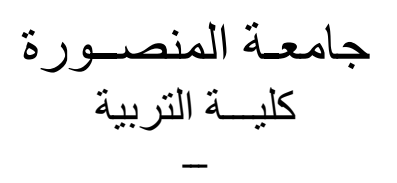

\title{
Improving EFL Grammar Achievement through Using Electronic Mind Maps
}

\author{
By \\ Doaa Marzouk Ahmed El-Kenany \\ A Teacher of English
}

Superwised by

\author{
Dr. Badran A. Hassan \\ Professor of Curriculum\& Instruction of \\ English \\ (TEFL) \\ Former Vice Dean for Postgraduate \\ Studies and Research \\ Faculty of Education \\ Mansoura University
}

\section{Dr.Asmaa A. Mostafa}

Professor of Curriculum\& Instruction of English (TEFL)

Former Dean of Faculty of Education Mansoura University

Vice President of the National Authority for Quality of Assurance and Accreditation

Journal of The Faculty of Education-Mansoura University

No. 113 - Jan . 2021 


\title{
Improving EFL Grammar Achievement through Using Electronic Mind Maps
}

\author{
Doaa Marzouk Ahmed El-Kenany
}

\begin{abstract}
The present study aimed at investigating the effect of using Mind mapping technique in improving EFL first year secondary stage students' English grammatical achievement. The instrument that were designed and used in the current study were an English Grammar Achievement test used as pre, post and follow- up test to measure students' grammatical achievement level and a questionnaire related to English grammar learning problems to identify the difficulties the EFL first year secondary stage students have in English grammar learning and achievement. The study adopted the experimental design using one group. The participant of the study consisted of thirty students selected from first year secondary stage of Ghazala Secondary School, Sinbillawin, Dakahlia governorate during the first semester of the academic year 2013-2014. The participants were taught using Mind Mapping technique. The collected data were analyzed and treated statistically using SPSS. Results provided evidence to the effectiveness of using Mind Mapping technique in improving the students' English grammar achievement. A number of recommendations concerning the use Mind Maps, English grammar learning and teaching, and course design were suggested.
\end{abstract}

Key Words: Electronic Mind Maps, English grammar, EFL, Achievement, Secondary stage students.

\section{Introduction}

Grammar plays an important role in language teaching. Grammar helps students speak English with organized and correct structures and thus develop the communicative skills of the language. Actually without grammar, we would have only individual words or sounds, pictures, and body expressions to communicate meaning. The problem with grammar is how to teach and present grammar to learners. Mind Maps can be a useful tool for students to learn grammar. They can be used to facilitate meaningful learning. Mind Maps can be used to generate, visualize, structure, classify ideas, and as an aid to study and organize information. Through branches and key images spread out from a central idea, it is possible for language learners to internalize, organize and brainstorm the grammatical rules of a target language. Mind Maps will not only facilitate understanding, but also memory. By remembering the rules and how they are related, knowledge can be stored into a long term memory. Students will then be able to recall 
the rules better when they need to apply them. However, there are few researches available concerning the effectiveness of using Mind Mapping technique in developing the EFL grammar achievement. The present study investigated the effectiveness of using Mind Mapping technique in improving the EFL grammar achievement of the first year secondary stage students compared to the effect of the traditional method that depended on the teacher guide.

\section{Background of the Problem}

Grammar teaching is essential part in English language learning. It helps students speak English with organized and correct structures and thus develop the communicative skills of the language. Grammar helps students speak English with organized and correct structures and thus develop the communicative skills of the language. According to Verghese (1989):

Acknowledge of grammar is perhaps more important to a secondlanguage learner than to a native speaker. This is because in the process of acquiring the language the native speaker has intuitively internalized the grammar of the language whereas the second language learner has to make a conscious effort to master those aspects of the language which account for grammaticality. It is, therefore, necessary for us, to whom English is a second language, to learn the grammar of the language.

Mind Mapping can be used in language teaching and learning in general and in teaching and learning grammar in specific. Buzan (2000) stated that Mind Mapping can be used to generate ideas, take notes, develop concepts and ideas, and improve memory. It is helpful for visual learners as they are illustrative tools that assist with managing thought, directing learning, and making connections (Stephens \& Hermus, 2007). It is a great way to introduce an overall topic, increase student involvement, and get thoughts down quickly.

In order to provide evidence for the problem of the study the researcher conducted a pilot study to determine students' English language grammar achievement level. The researcher conducted a pilot study to a sample of (60) students from Ghazala secondary School, Sinbillawin, Dakahlia governorate, during the first semester of the academic year 20132014. The researcher designed an English Grammar Achievement test (Appendix A) based on students prescribed book as well as a questionnaire related to English grammar learning problems (Appendix B). The test and the questionnaire were designed by the researcher and validated by 
specialists and professors in the field of EFL and methods of teaching $(\mathrm{N}=5)$ and TEFL supervisors and teachers $(\mathrm{N}=3)$. (Appendix $\mathrm{C}$ )

Analyzing the results, the following points can be concluded:

1. Most students had problems in English language grammar achievement.

2. Most students were not satisfied with the teaching strategies their teachers use.

3. Students considered English grammar as a difficult component.

4. Students realized the importance of English grammar as a course of their study.

\section{Statement of the Problem}

Based on the literature review, related studies and pilot study results, the problem of the study can be stated as follows: First year EFL secondary stage students' level in the English Language grammar was below average. They seemed to encounter difficulty in English grammar achievement. Thus, students needed to be taught English grammar through an interactive technique to cater to their individual styles of learning. Therefore, the present study had investigated the effectiveness of using Mind Mapping technique in improving English grammar achievement of the first year secondary stage students compared to the effect of the traditional method that depended on the teacher guide.

\section{Questions}

The problem of the study was explored through answering the following questions:

1. What are Mind Maps that are used to improve English grammar achievement of the first year EFL secondary stage students?

2. What is the effectiveness of using Mind Maps in improving English grammar achievement of the first year EFL secondary stage students?

\section{Purpose}

The study aimed at:

1. Assessing the present level of the EFL first year secondary Stage students' grammar achievement.

2. Identifying whether EFL students faced problems with regard to English grammar learning.

3. Teaching English grammar using Mind Mapping technique to the first year EFL secondary stage students. 
4. Investigating the effect of using Mind Mapping technique in improving students' English grammar achievement level.

5. Contributing to improving the process of teaching English in general and English grammar in particular to first year secondary stage students using Mind Mapping technique.

\section{Significance}

The present study hoped to contribute to:

1. Directing the attention of EFL teachers towards the importance of teaching grammar as a basis for enhancing communication skills.

2. Directing the attention of EFL teachers to the importance of using Mind Maps in improving teaching grammar.

3. Teaching students how to make good use of Mind Maps in learning English grammar in particular and in learning English language skills in general.

4. Paving the way for other researchers to investigate the effectiveness of using Mind Map in improving other language skills.

\section{Variables}

The current study included the following variables;

1. Independent variable : Mind Mapping technique

2. Dependent variable: the achievement of EFL first year secondary stage students in English grammar.

\section{Definition of Terms}

Based upon the review of the related literature, the following terms could be defined:

\section{English Grammar}

Harmer (2001) defined grammar of a language as "the description of the ways in which words can change their forms and can be combined into sentences in that language".

Thornbury (2004) stated that grammar is "the study of what forms or structures are possible in a language".

\section{Achievement}

According to Richards, Platt and Platt (1992) achievement means "how much of a language someone has learned with reference to a particular course of study or program of instruction" (p.3). 
For the purpose of the study, English grammar achievement is defined operationally as the scores students get on the English Grammar Achievement test prepared by the researcher.A high score refers to the student's high achievement in English language grammar while the low score refers to the student's low achievement in English language grammar.

\section{Electronic Mind Map}

Mind Map is a diagram used to represent words, ideas, tasks or other items linked to and arranged around a central key word or idea. It is used to generate, visualize, structure and classify ideas (Buzan, 1991).

A Mind Map is a graphic organizer in which the major categories radiate from a central image and lesser categories are portrayed as branches of larger branches (Budd, 2004).

For the purpose of the study, Mind Map is defined operationally as a special kind of brain-friendly visual diagram prepared by the researcher and the students using the electronic Mind Map program; "iMindMap 7.0". certain rules and steps are used such as lines, colors, characters, numbers, symbols, images, pictures, keywords, branches or some way of showing connections between ideas related to English grammar that generated on student mind map. It helps students to think, imagine, and remember English language grammar easily.

\section{Review of Literature}

\section{Mind Map}

A Mind Map is one type of Visual-Association-Tools (VATs); it is a graphic, networked method of sorting, organizing and prioritizing information, using key or trigger words and images. Each of the memory triggers on Mind Maps is a key to unlocking facts, ideas and information. Mind Map's effectiveness lies in its dynamic shape and form, which is drawn alike a brain cell and it is designed to encourage the brain to work in a way that is fast, efficient, and in the style that it does naturally. (Buzan, 2006)

According to Buzan and Buzan (1996), Mind Map is an expression of radiant thinking and is therefore a function of the human mind. It is considered as a powerful graphic technique which provides a universal key to unlocking the potential of the brain. Krasnic (2011) also defined Mind Mapping or visual maps as - a graphic tool used to collect, create, manage and exchange information. It represents information via the special 
organization of concepts, topics, ideas, words, or other items linked to and arranged in a radial pattern round a central concept.

\section{Importance of Mind Mapping}

Developed by Tony Buzan in 1970, Mind Mapping is a revolutionary system for capturing ideas and insights horizontally on a sheet of paper. It is an extremely effective technique for sharpening the thinking and learning process (Buzan, 1989). Mind mapping can be used to generate ideas, take notes, develop concepts and ideas, and improve memory (Buzan, 2000). It can be used in nearly every activity where thought, planning, recall or creativity is involved (Buzan, 1989).Mind Maps can unleash the minds potential because it mirrors the associative functioning of the brain which is radiant and holistic (Buzan,1996).Moreover, by adopting Mind Maps in the learning development, the whole brain will be involved in this process and it will be possible to perceive a vast improvement in the learning approach (Buehl, 2008). The clue to the Mind Map's effectiveness lies in its dynamic shape and form. It is drawn in the shape and form of a brain cell and is designed to encourage your brain to work in a way that is fast, efficient, and in the style that it does naturally. Every time we look at the veins of a leaf or the branches of a tree we see nature's 'Mind Maps' echoing the shapes of brain cells and reflecting the way we ourselves are created and connected (Buzan, 1996).

Moreover, Mind Maps can serve in improving and increasing students 'motivation. It gives pupils opportunities for expressing themselves and their creativity, for becoming enthusiastic about the subject. Mind Mapping has been shown to bring a renewed sense of enthusiasm to the classroom because it increases student confidence and sense of skill in mastering assigned materials (Mento et al., 1999). Mind Mapping activities require students to actively engage in their learning. Mind Map motivate, inspire and help learners acquire knowledge in an enjoyable and easy way. When used as a part of instruction, this type of mapping technique has been shown to increase students 'achievement scores (Horton et al., 1993) and knowledge retention (Nesbit \& Adescope, 2006). Mind Mapping enables students to keep the whole knowledge 'picture' in view at all times, thus giving students a more balanced and comprehensive understanding of the subject in its entirety.

They take up far less space than linear notes. Between 10 and 1000 pages of text can be summarized on one large Mind .They give your brain a central focus and structure within which to integrate your knowledge of any 
subject. They increase their brains' 'hunger' for knowledge. They allow them to relate their own thoughts and ideas to those expressed in books, lectures or presentations. Mind Mappings are far more effective and efficient for review purposes. They enhance students' memory and understanding of textbooks, study guides, lectures and coursework, enabling them to excel in any course of study. Figure (1) shows some of Mind Maps benefits.

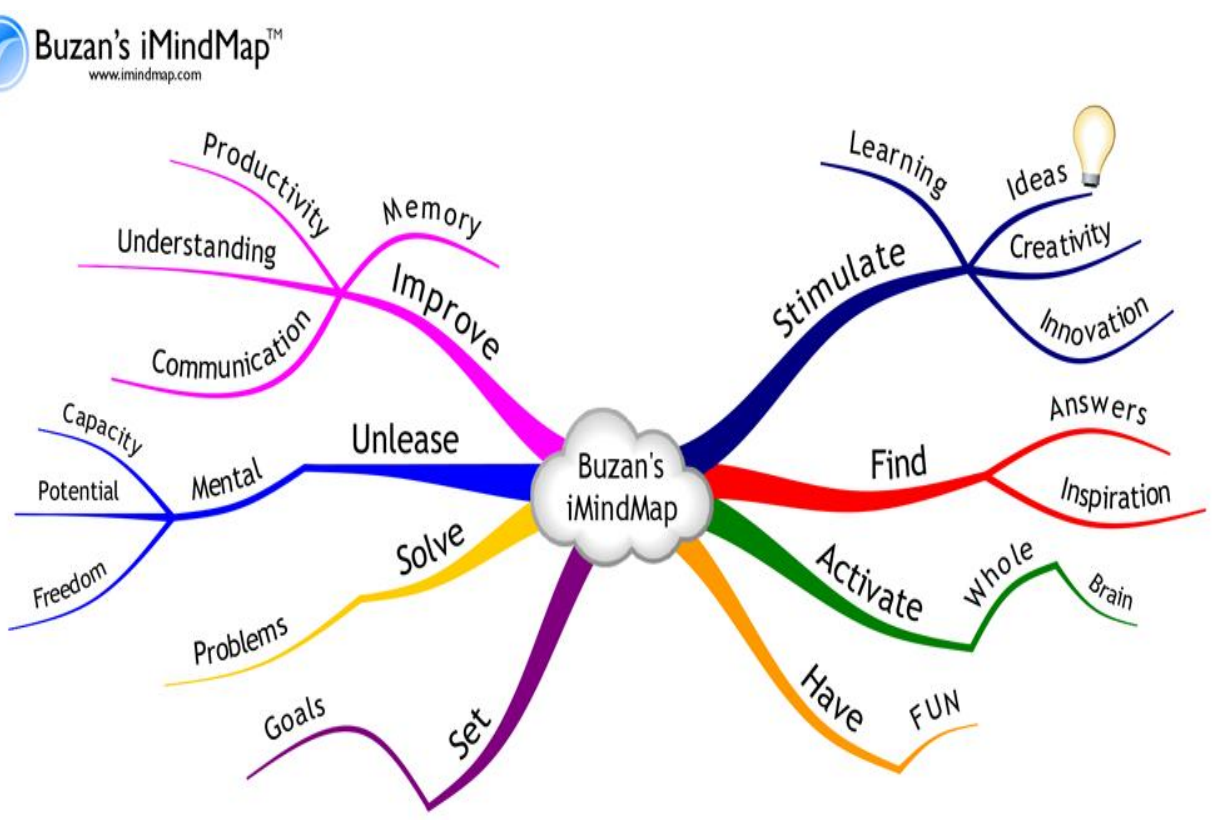

Figure (1): Benefits of Mind Maps available at:

http://open-tube.com/wp-content/uploads/2009/02/buzan-mindmap.png

\section{Guidelines for Drawing Mind Map}

In order to create a Mind Map, only a sheet of paper, colors, the brain and imagination are needed. The same as the main engines which turn on our brain: imagination and association (Buzan, 2005). Mind mapping actually has four essential characteristics: The subject attention is crystallized in a central image, the main themes of the subject radiate from the central image as branches, branches comprise a key image or key word printed on an associated line, and the braches form a connected nodal structure (Ibrahim, 2013). 
Buzan (2005) explained the steps in how to make mind mapping: Take a piece of white paper and it is in a landscape position.

- Starting by drawing a colored image in the centre of the paper and write the key word with capital letters.

- Choosing a color and draw the main themes of the Mind Mapping on the thick branches radiating out from the central image.

- Adding other main themes branches around the map.

- Making thick and colorful branches spanning out from your Mind Map.

- Writing basic ideas about the key word and still use the capital letters.

- Adding an image to all the main branches to represent each key theme and also use images to visualize every important key word on your map.

\section{Electronic Mind Map}

Electronic Mind Maps are effective tools that enhance memory and retrieval of information and generate new creative ideas as they work at the same steps of a human mind which activate both human spheres and arrange information in a way helps the mind to read and remember information instead of linear thinking. The hand written Mind Map is paper based, but with the emergence of some software, the electronic Mind Maps started to appear (Dara, 2010).

Electronic Mind Maps are more effective and attractive than traditional ones, since they depend on using professionally fast and specialized computer software which includes photos, colors, and drawings that attract the reader. Hence, some authors suggested using e-Mind Maps in an early education stage as they help students organize ideas and information (Davis, 2010).Additionally, their preparation does not require high skills since software contain drawings, clip arts, symbols, and images that can be easily inserted (Elabady \& Jradat, 2015; Boyson, 2009). It looks like Free creative Sketches based on specialized computerized programs and they consist of branches radiating from the center lines using words and symbols, colors, and are used to represent relationships between ideas, information and require spontaneous thinking during creating.

Some of the most popular and effective examples of Mind Mapping software available in education today are MindMeister, MindMaple, Inspiration, mindmapper professional, matchware, The Brain, and Bubbl.us, also one can use Microsoft office to create E-Mind Map. E-Mind Mapping 
provides students with multimedia, such as images, various shapes of lines, sound effects, colors, dictionary provided with native speaker voice, and various kind of font. These potentials of E- Mind Mapping attract students'attentions. Mohaidat (2018) claimed that electronic Mind Mapping helped students speed up their learning process and find knowledge faster by drawing out a diagram that illustrated the basic concept of the main and sub ideas. Electric Mind Maps have also proven their effectiveness in activating memory, raising the level of understanding of reading texts, and increasing their efficiency in organizing ideas and presenting them to others. Moreover, using E-Mind Mapping gives teachers the ability and freedom to express ideas and show interrelationships between concepts and content visually in network not in linear structures that help learners to remember (Ruffini, 2008).

\section{Grammar}

Thornbury (2004) extended grammar definition to include its functional dimension. He defines grammar as a process for making communication clear when contextual information is lacking. It is also defined as the set of structural rules that govern the composition of clauses, phrases and words in any given natural language. The term refers also to the study of such rules, and this field includes morphology, syntax, and phonology, often complemented by phonetics, semantics and pragmatics (Harmer, 2001).

In addition, Obaid (2010) believed that grammar is a set of directions and orders that control the use of a language and organize the words to transfer an expressive language. Also, Singh (2011) indicated that Grammar is one of the most major elements that a language has, which refers in a word to the correctness and accuracy in a language. That means, it describes, formulates and shapes language takes morphologically, phonologically, syntactically and semantically. Abu Taleb (2015) also mentioned that grammar is the systematic and arranged structure of language. It is the rules in which it can make and produce a meaningful words, sentences and paragraphs by the users of a language.

\section{Mind Map and English Grammar Learning}

In English grammar learning, Mind Maps work well because they engage the visual intelligence and provide a way to navigate a much larger space of English grammar ideas in a smaller visual field. Once students have created their Mind Map, they will notice that instead of having pages and pages of boring linear notes, they have a single page that contains all the key 
points that you need to remember. They will instantly see the connections and links between different ideas and thoughts and can help them quickly gain insight into the big picture as it represented on the piece of paper in front of them. Students are able to use color, icons, symbols, graphics and their own personal words to make sure they understand it well and recall information in an easier way. Consequently, this way is resulting in a noticeably improved memory. Students will then be able to recall the rules better when they need to apply them. They are easy to review. By remembering the rules and how they are related, knowledge can be stored into a long term memory.

In addition, teacher can use Mind Maps to provoke learning and attract students' attention when he/she introduces a new topic but they are also very useful for systematization and revision. Once students become familiar with the concept, teacher should incite them to make their own Mind Maps. Students may do this in groups or individually if the given problem is not particularly demanding. Instead of giving them hundreds of exercises for the Simple Present Tense, make them draw a map of it. Teacher should help and guide them in this process. Mind Maps can be used in different stages during the lesson. For example, as a revision, when presenting a new lesson, through exercises as in fill in the blanks, design a Mind Maps about.... and at the end of the lesson as a summary or an assessment of what students learned. It can be used with tenses, parts of speech, prepositions, verbs, nouns, adjectives and every aspect of English grammar.

\section{Related Studies}

In learning/teaching English, Bekti (2006) investigated a study aimed at showing how Mind Mapping technique can be applied as a technique in teaching reading comprehension and to find out whether this technique can affect the students' reading comprehension achievements. The study adopted the experimental design. The population of this study was the eleventh grade students of SMK Negeri (8) Semarang in the academic year of (2006/2007). The sampling process was administered by applying cluster random sampling. There were (180) students of the eleventh grade and 30 students were taken as the experimental group and taught by using Mind Mapping technique whereas other (30) students were the control group and taught without the use of Mind Mapping technique. The result showed that there is a significant difference in the reading comprehension achievement between the students who were taught by using Mind Mapping technique and those who were taught conventionally. 
Aljaser (2016) also conducted a study to identify the effect of using electronic Mind Maps on the academic achievement of the fifth-grade primary female students in the English language curriculum compared to the traditional teaching method adopted in the teacher's guide. It also aimed to indicate the attitudes of the fifth-grade female students towards the use of electronic Mind Maps in understanding the study unit adopted in this study. The study utilized the quasi-experimental method applied to two groups: experimental and control. The population of the study consisted of the fifth grade of primary school female students, who studied in Ashbeelya Private School in Riyadh for the academic year (2016/2017), and the participants ages ranged from (10 to 12) years. The sample of the study is consisted of 30 fifth-grade female students, divided into experimental group (15 students) and control group (15 students). The study resulted that there was statistically significant difference between the mean score of the experimental group and the control one in the post achievement test scale in favor of the experimental group. The effect size of using Mind Maps was high. There was statistically significant difference between the mean score of the experimental and control group scores in the post achievement test of the attitude towards learning English in favor of the experimental group.

Few studies have been carried out on using Mind Map technique to enhance learning/teaching English grammar language. Harbi (2012) conducted a study that aimed at investigating the effect of using Mind Mapping technique on the mastery of grammar among tenth graders in Gaza governorates. To achieve this aim, the researcher adopted the quasi experimental approach. The sample of the study consisted of (67) male students from Hamad Bin Khaliefa (B) Secondary School NorthGaza governorate. The study subjects were divided into two equivalent groups: a control group, (34) students, and an experimental one, (33) students. The Mind Mapping technique was used in teaching the experimental group, while the traditional method was used with the control one in the second term of the school year of (2012-2013). The research findings showed that there is statistically significant difference between the mean score of the experimental group students (using Mind Maps) and those of the control group students (using traditional way) on the post grammar achievement test .This significant difference is in favor of the first experimental group. The study recommended the necessity of using Mind Mapping Technique in teaching the grammar of English language to improve outcomes of grammar teaching. 
Furthermore, Gomaan (2015) conducted a study to investigate the effect of using Mind Maps to learn English grammar to the Third Secondary class Students in Sabya. In this study, the use of Mind Maps, as an instructional tool in learning grammar, is compared to the conventional method that depends on verbal explanation and the use of student book, the board and board markers. To achieve this purpose, the researcher applies a quasi-experimental study during the second semester of the academic year $(1435-1436 \mathrm{AH})$. The sample of the study consisted of (40) students, were chosen intentionally from Damad Secondary School in Sabya. The sample of the study was divided into two groups. One of the two groups was experimental and it was taught using the Mind Maping technique. The other was a control group and it was taught using the traditional method. Pre/post tests have been applied to both groups.

The research findings showed that there is statistically significant difference at (0.05) level between the mean score of the experimental group students (using Mind Maps) and those of the control group students (using traditional way) on the post Grammar Achievement test .This significant difference is in favor of the first experimental group.

\section{Hypothesis}

The study verified the following hypotheses: There is statistically significant difference between the mean score of the experimental group in the pre, post and follow-up administrations of the English Grammar Achievement test (the dimensions and the total score) in favor of the post administration compared to the pre-administration and in favor of the follow-up administration compared to the pre and the post administrations.

\section{Method}

The method of the study includes the participant, the instrument, the design, and procedures that were followed to carry out the study.

\section{Participants}

The participants of the study consisted of thirty students randomly selected from first year secondary stage of Ghazala secondary School, Sinbillawin, Dakahlia governorate during the first semester of the academic year 2013-2014.

\section{Design}

The study adopted the quasi-experimental design using one group for 3 measures (pre- post -follow up) . The participants were taught using Mind Mapping technique. 


\section{Instruments}

For the purpose of the study,

1.An English Grammar Achievement test designed to be used as pre, post and follow-up test to measure students' English grammar achievement. (Appendix D)

2.Electronic Mind Map program; iMindMap 7.0 for teaching English grammar lessons embedded in the first four units from the 1st year secondary stage English book of the academic year 2013/2014. (Appendix E)

\section{Test Validity}

First: Inter-rater Validity: The first form of the test was given to specialists and professors in the field of EFL and methods of teaching $(\mathrm{N}=8)$ and TEFL supervisors and teachers $(\mathrm{N}=6)$ (Appendix $\mathrm{F}$ ) to evaluate the test questions in order to determine:

1. The suitability of time given for each questions.

2. The suitability of test language and items for the study sample.

3. The suitability of the test for the learners' age.

4. To decide how far the test was appropriate to measure the stated objectives.

5. Items representativeness of the cognitive domain levels.

6. To decide the equivalence of the three English grammar achievement forms to be used as pre, post, and follow up tests.

Table (1) reveals that the percentage of jury agreement on the test items was more than $80 \%$ (about 12 jurors). This indicates a good level of jury validity for the test items.

The following table clarifies the percentage of agreement of the jury members on the test items. 
Table (1)

The percentage of agreement of the jury members on the test items

\begin{tabular}{|c|c|c|c|c|c|c|c|c|c|}
\hline Item & $\begin{array}{c}\text { Percentage } \\
\text { of Agreement }\end{array}$ & Item & $\begin{array}{c}\text { Percentage } \\
\text { of Agreement }\end{array}$ & Item & $\begin{array}{c}\text { Percentage } \\
\text { of Agreement }\end{array}$ & $\begin{array}{c}\text { Concordance } \\
\text { Coefficient }(W)\end{array}$ & $\begin{array}{c}\text { Chi- } \\
\text { Square } \\
\chi^{2}\end{array}$ & df & sig \\
\hline 1 & $100 \%$ & 23 & $93 \%$ & 45 & $100 \%$ & \multirow{22}{*}{1.549} & \multirow{22}{*}{1536.608} & \multirow{22}{*}{61} & \multirow{22}{*}{0.001} \\
\hline 2 & $93 \%$ & 24 & $100 \%$ & 46 & $93 \%$ & & & & \\
\hline 3 & $93 \%$ & 25 & $100 \%$ & 47 & $100 \%$ & & & & \\
\hline 4 & $100 \%$ & 26 & $100 \%$ & 48 & $93 \%$ & & & & \\
\hline 5 & $86 \%$ & 27 & $93 \%$ & 49 & $93 \%$ & & & & \\
\hline 6 & $93 \%$ & 28 & $93 \%$ & 50 & $100 \%$ & & & & \\
\hline 7 & $100 \%$ & 29 & $100 \%$ & 51 & $100 \%$ & & & & \\
\hline 8 & $93 \%$ & 30 & $100 \%$ & 52 & $93 \%$ & & & & \\
\hline 9 & $79 \%$ & 31 & $93 \%$ & 53 & $100 \%$ & & & & \\
\hline 10 & $86 \%$ & 32 & $100 \%$ & 54 & $100 \%$ & & & & \\
\hline 11 & $93 \%$ & 33 & $65 \%$ & 55 & $93 \%$ & & & & \\
\hline 12 & $86 \%$ & 34 & $86 \%$ & & & & & & \\
\hline 13 & $100 \%$ & 35 & $100 \%$ & & & & & & \\
\hline 14 & $100 \%$ & 36 & $93 \%$ & & & & & & \\
\hline 15 & $93 \%$ & 37 & $100 \%$ & & & & & & \\
\hline 16 & $93 \%$ & 38 & $93 \%$ & & & & & & \\
\hline 17 & $86 \%$ & 39 & $100 \%$ & & & & & & \\
\hline 18 & $100 \%$ & 40 & $93 \%$ & & & & & & \\
\hline 19 & $93 \%$ & 41 & $93 \%$ & & & & & & \\
\hline 20 & $93 \%$ & 42 & $65 \%$ & & & & & & \\
\hline 21 & $100 \%$ & 43 & $100 \%$ & & & & & & \\
\hline 22 & $100 \%$ & 44 & $93 \%$ & & & & & & \\
\hline
\end{tabular}

Table (1) shows that the percentage of jury agreement on test items was among ( $86 \%$ to $100 \%)$. This indicates a good level of jury validity for the test items. On the other hand, the percentage of Jury agreement on test items numbers (9-33-42) less than $80 \%$.The researcher deleted them. The items number became (52). The coefficient of Concordance (W) was (1.549) and Chi-Square values was (1536.608). The significance level is about $(0,001)$. This indicates a significant agreement among the jurors on the importance of the test items. 


\section{Second: Convergent validity}

\section{a. convergent validity for each item}

The Grammar Achievement test was administered to standardization sample (about 115 male and female students of the first secondary stage). Pearson corrected item correlation coefficient was calculated for the score of each item and the total score of the level that it belonged to after deleting the score of the item from the total score of its level (Abu Allam, 2006). An item was considered valid if its correlation coefficient of the cognitive level which it represented was $\geq(0.3)$ and had statistical significance as showing in the following table.

\section{Table (2)}

Pearson corrected item correlation coefficients values between the score of each item and the total score of each cognitive level that it belonged to (Validity for test items)

\begin{tabular}{|l|l|l|l|l|l|l|l|l|l|l|l|}
\hline \multicolumn{2}{|l|}{ Knowledge } & \multicolumn{2}{l|}{ Comprehension } & \multicolumn{2}{l|}{ Application } & \multicolumn{2}{l|}{ Analysis } & \multicolumn{2}{l|}{ Synthesis } \\
\hline item & $\begin{array}{l}\text { correlation } \\
\text { coefficient }\end{array}$ & item & $\begin{array}{l}\text { correlation } \\
\text { coefficient }\end{array}$ & item & $\begin{array}{l}\text { correlation } \\
\text { coefficient }\end{array}$ & item & $\begin{array}{l}\text { correlation } \\
\text { coefficient }\end{array}$ & item & $\begin{array}{l}\text { correlation } \\
\text { coefficient }\end{array}$ & item & $\begin{array}{l}\text { correlation } \\
\text { coefficient }\end{array}$ \\
\hline $\mathbf{1}$ & $0.66^{* *}$ & 1 & $0.49^{*}$ & 1 & $0.48^{*}$ & 1 & $0.77^{* *}$ & 1 & $0.45^{* *}$ & 11 & $0.63^{* *}$ \\
\hline $\mathbf{2}$ & $0.47^{*}$ & 2 & $0.65^{* *}$ & 2 & $0.62^{* *}$ & 2 & $0.69^{* *}$ & 2 & $0.52^{* *}$ & 12 & $0.72^{* *}$ \\
\hline $\mathbf{3}$ & $0.55^{*}$ & 3 & $0.54^{*}$ & 3 & $0.59^{*}$ & 3 & $0.55^{*}$ & 3 & $0.65^{* *}$ & 13 & $0.62^{* *}$ \\
\hline $\mathbf{4}$ & $0.58^{* *}$ & 4 & $0.67^{* *}$ & 4 & $0.52^{*}$ & 4 & 0.11 & 4 & $0.66^{* *}$ & 14 & 0.21 \\
\hline $\mathbf{5}$ & 0.13 & 5 & $0.51^{*}$ & 5 & $0.49^{* *}$ & 5 & $0.66^{* *}$ & 5 & $0.59^{* *}$ & 15 & $0.69^{* *}$ \\
\hline $\mathbf{6}$ & $0.55^{*}$ & 6 & $0.47^{*}$ & 6 & $0.58^{* *}$ & 6 & $0.50^{*}$ & 6 & $0.71^{* *}$ & 16 & $0.71^{* *}$ \\
\hline $\mathbf{7}$ & $0.67^{* *}$ & 7 & 0.08 & 7 & 0.15 & 7 & $0.75^{* *}$ & 7 & $0.56^{* *}$ & & \\
\hline $\mathbf{8}$ & $0.65^{* *}$ & 8 & $0.65^{* *}$ & 8 & $0.66^{* *}$ & & & 8 & $0.65^{* *}$ & & \\
\hline $\mathbf{9}$ & $0.65^{* *}$ & 9 & $0.56^{* *}$ & 9 & $0.56^{* *}$ & & & 9 & $0.68^{* *}$ & & \\
\hline & & 10 & 0.05 & 10 & $0.62^{* *}$ & & & 10 & $0.66^{* *}$ & & \\
\hline
\end{tabular}

${ }^{* *}$ Significant at $(.01)$

*Significant at (.05)

The previous table clarifies that:

1. In the knowledge level: Pearson corrected item correlation coefficients values ranged between (0.47) and (0.67). They were all statistically significant except the item number (5); it was less than 0.3 . So, it was deleted. Thus, the number of the items became (8) items with strong and important corrected correlation coefficients (Guillford, 1956).

2. In the comprehension level: Pearson corrected item correlation coefficients values ranged between (0.47) and (0.67). They were all statistically significant except the item number (7 and 10); they were 
less than 0.3. So, it was deleted. Thus, the number of the items became (8) items with strong and important corrected correlation coefficients (Guillford, 1956).

3. In the application level: Pearson corrected item correlation coefficients values ranged between (0.48) and (0.66). They were all statistically significant except the item number (7); it was less than 0.3. So, it was deleted. Thus, the number of the items became (9) items with strong and important corrected correlation coefficients (Guillford, 1956).

4. In the analysis level: Pearson corrected item correlation coefficients values ranged between $(0.50)$ and $(0.77)$. They were all statistically significant except the item number (11); it was less than 0.3. So, it was deleted. Thus, the number of the items became (6) items with strong and important corrected correlation coefficients (Guillford, 1956).

5. In the synthesis level: Pearson corrected item correlation coefficients values ranged between $(0.45)$ and $(0.72)$. They were all statistically significant except the item number (14); it was less than 0.3. So, it was deleted. Thus, the number of the items became (15) items with strong and important corrected correlation coefficients (Guillford, 1956).

\section{b. Convergent validity for each level}

The Grammar Achievement test was administered to standardization sample (about 115 male and female students of the first secondary stage). Pearson corrected correlation coefficient of each level was calculated for the score of level and the total score of the test after deleting the score of the level from the total score of the test (Abou Allam, 2006). The level was considered valid if its correlation coefficient was (0.3) and had statistical significance as showing in the following table.

Table (3)

Pearson corrected correlation coefficients values between the total score of each cognitive level and the total score of the achievement test

\begin{tabular}{|l|l|l|l|}
\hline item & \multicolumn{1}{|c|}{ The cognitive level } & \multicolumn{1}{c|}{$\begin{array}{c}\text { Pearson corrected } \\
\text { correlation coff. }\end{array}$} & Significance \\
\hline $\mathbf{1}$ & Knowledge and remember & 0.79 & 0.001 \\
\hline $\mathbf{2}$ & Comprehension & 0.76 & 0.001 \\
\hline $\mathbf{3}$ & Application & 0.78 & 0.001 \\
\hline $\mathbf{4}$ & Analysis & 0.69 & 0.001 \\
\hline $\mathbf{5}$ & Synthesis & 0.81 & 0.001 \\
\hline
\end{tabular}


Results in table (3) illustrate that Pearson corrected correlation coefficients values between the level score and the total score of the test ranged between (0.69) and (0.81). They are all strong and important (Guillford, 1956). All values were statistically significant at (0.001) .The results indicate the validity of the test.

Results of the convergent validity proved that all items and levels of the test had suitable score of validity.

\section{Test-Reliability}

\section{First: Cronbach's Alpha Coefficient Reliability:}

Reliability for the test was calculated using Cronbach's Alpha coefficient reliability for the items of test levels and that of all items of the test.

Table (4) Shows Cronbach's Alpha reliability values for the items of test levels and that of all items of the test.

\section{Table (4)}

Cronbach's Alpha reliability values for the items of test levels and that of all items of the test

\begin{tabular}{|l|l|l|l|}
\hline \multicolumn{1}{|c|}{ Cognitive levels } & \multicolumn{1}{c|}{ Items number } & Cronbach's Alpha & \multicolumn{1}{c|}{ Sig. } \\
\hline Knowledge & 8 & 0.83 & Accepted \\
\hline Comprehension & 8 & 0.77 & Accepted \\
\hline Application & 9 & 0.75 & Accepted \\
\hline Analysis & 6 & 0.79 & Accepted \\
\hline Synthesis & 15 & 0.80 & Accepted \\
\hline The whole test & 46 & 0.87 & Accepted \\
\hline
\end{tabular}

The previous table shows that all Cronbach's Alpha coefficients of the levels ranged between (0.75) and (0.83), and that of the whole test is (0.87).The whole values are more than $(0.5)$ which means that the test is highly reliable and accepted.

\section{Second: Test Retest Reliability}

In order to establish the reliability of the test, it was administered to a randomly selected group of (30) first year secondary school students from the standardization sample (115 students). Those students were neither included in the experimental nor in the control group. Then, the test was readministered after two weeks to the same students. The correlation between the two administrations was estimated using the following Pearson correlation coefficient.

The following table clarifies the reliability results by reapplying the test. 


\section{Table (5)}

The values of reliability coefficient of English Grammar Achievement test reapplication (the cognitive levels and the total test)

\begin{tabular}{|l|l|l|}
\hline \multicolumn{1}{|c|}{ cognitive level } & $\begin{array}{c}\text { Correlation Coefficient between the 2 } \\
\text { administrations of the test }\end{array}$ & Sig. \\
\hline Knowledge & 0.852 & 0.001 \\
\hline Comprehension & 0.811 & 0.001 \\
\hline Application & 0.801 & 0.001 \\
\hline Analysis & 0.832 & 0.001 \\
\hline Synthesis & 0.833 & 0.001 \\
\hline The whole test & 0.885 & 0.001 \\
\hline
\end{tabular}

The previous table clarifies that the reliability coefficient of the cognitive levels ranged between (0.801-0.852) and that of the total test was about (0.885).The values were statistically significant at (0.001) .This means that the correlation coefficient of the test reapplication is relatively high (Guillford, 1956). Therefore, the test was considered reliable for the purpose of the current study.

Facility, Difficulty, and Discrimination Coefficients of the Grammar Achievement Test Items

Facility, difficulty, and discrimination coefficients of the Grammar Achievement test items were calculated .The facility coefficient should not be less than (0.3) and difficulty coefficient should not be more than (0.7). Moreover, the discrimination coefficient should not be less than $(0.25)$. The results clarify the facility, difficulty, and discrimination coefficients of the Grammar Achievement test items.(Appendix G)

The facility coefficient ranged between (0.429) and (0.659) and the values were more than (0.3). The difficulty coefficient ranged between (0.341) and (0.571) and the values were less that (0.7).Moreover, the discrimination coefficient of the test items was calculated and it ranged between (0.474) and (0.500). The values were more than $(0.3)$. Thus, these values are considered acceptable and suitable and indicated the questions ability of showing distinctions among students.

The results are considered acceptable and indicate the questions ability of showing distinctions among students and the test is considered applicable for the purpose of the study.

\section{Test Time}

It was estimated that a period of (90) minutes would provide ample time for students to complete the test. No one needed an extension of time to complete the test. The time was estimated by calculating the mean time for 
all students having the test. Consequently, the test was considered ready to be applied to the main sample of the experimental treatment.

\section{Procedures}

To answer the questions of the study, the following procedures followed:

1. Reviewing literature in the field of Mind Maps and English grammar learning and teaching.

2. Reviewing studies related to Mind Mapping technique and its effect on English grammar language.

3. Preparing an English Grammar Achievement test to determine the first year secondary stage students level in English grammar achievement and a questionnaire to identify the problems the first year secondary stage students face in English grammar achievement.

4. Presenting the test and the questionnaire to a group of jurors to ensure their suitability to be used.

5. Applying the test and the questionnaire to the pilot study (60 students) to identify the students' level and the problems they face in English grammar achievement.

6. Identifying the grammar lessons that are included in the student textbook in (Units: 1, 2, 3, and 4).

7. Designing English Grammar Achievement test to be used as pre, post and follow up test.

8. Using the test to measure its validity and reliability.

9. Designing the grammar lessons included in the student textbook in (Units: 1, 2, 3, 4) using Mind Mapping technique.

10. Selecting the participant of the study randomly.

11. Pre-administering of the grammar test.

12. Teaching grammar lessons using Mind Mapping technique.

13. Post- administering of the grammar test.

14. Administering the follow-up test after about 3 weeks from the postadministering to measure how far students can retain the achieved level.

15. Comparing the results of the post and follow-up administrations of the English Grammar Achievement test.

16. Comparing the results of the pre, post and follow-up administrations of the English Grammar Achievement test.

17. Analyzing the data statistically.

18. Discussing the results and providing conclusions and recommendations. 


\section{Results and Discussions}

Results were statistically analyzed in terms of the hypothesis. It is discussed in the light of the theoretical background and related studies.

In order to verify the hypothesis, ANOVA Repeated Measure (f_R) was used. The following table clarifies " $F$ " value and its significance of the difference among the pre, post and follows-up administrations of the English Grammar Achievement test of the experimental group.

The table shows "F "value and its significance of the difference among the pre, post and follow-up administrations of the English Grammar Achievement test.

Table (6)

" $F$ "value and its significance of the difference among the pre, post and follow-up administrations of the English Grammar Achievement test of the experimental group

\begin{tabular}{|c|c|c|c|c|c|c|c|}
\hline The level & $\begin{array}{l}\text { source of } \\
\text { variance }\end{array}$ & $\begin{array}{l}\text { sum of } \\
\text { squares }\end{array}$ & d.f & $\begin{array}{c}\text { Mean } \\
\text { squares }\end{array}$ & $\mathbf{f}$ & Sig. & $\begin{array}{c}\text { Effect Size } \\
\text { (Partial Eta } \\
\text { Squared }\end{array}$ \\
\hline \multirow[t]{2}{*}{ knowledge } & $\begin{array}{l}\text { Between } \\
\text { measurements }\end{array}$ & 241.689 & 2 & 120.844 & \multirow[t]{2}{*}{160.59} & \multirow[t]{2}{*}{0.01} & \multirow[t]{2}{*}{$\begin{array}{l}0.847 \\
(84.7 \%)\end{array}$} \\
\hline & Error & 43.64 & 58 & 0.752 & & & \\
\hline \multirow[t]{2}{*}{ comprehension } & $\begin{array}{l}\text { Between } \\
\text { measurements }\end{array}$ & 279.200 & 2 & 139.600 & \multirow[t]{2}{*}{274.78} & \multirow[t]{2}{*}{0.01} & \multirow[t]{2}{*}{$\begin{array}{l}0.905 \\
(90.5 \%)\end{array}$} \\
\hline & Error & 29.47 & 58 & 0.508 & & & \\
\hline \multirow[t]{2}{*}{ Application } & $\begin{array}{l}\text { Between } \\
\text { measurements }\end{array}$ & 347.822 & 2 & 173.911 & \multirow[t]{2}{*}{679.5} & \multirow[t]{2}{*}{0.01} & \multirow[t]{2}{*}{$\begin{array}{l}0.959 \\
(95.9 \%)\end{array}$} \\
\hline & Error & 14.844 & 58 & 0.256 & & & \\
\hline \multirow[t]{2}{*}{ Analysis } & $\begin{array}{l}\text { Between } \\
\text { measurements }\end{array}$ & 118.422 & 2 & 59.211 & \multirow[t]{2}{*}{159.16} & \multirow[t]{2}{*}{0.01} & \multirow[t]{2}{*}{$\begin{array}{l}0.846 \\
(84.6 \%)\end{array}$} \\
\hline & Error & 21.578 & 58 & 0.372 & & & \\
\hline \multirow[t]{2}{*}{ Synthesis } & $\begin{array}{l}\text { Between } \\
\text { measurements }\end{array}$ & 1598.022 & 2 & 799.011 & \multirow[t]{2}{*}{772.66} & \multirow[t]{2}{*}{0.01} & \multirow[t]{2}{*}{$\begin{array}{l}0.976 \\
(97.6 \%)\end{array}$} \\
\hline & Error & 59.98 & 58 & 1.034 & & & \\
\hline \multirow[t]{2}{*}{ Total score } & $\begin{array}{l}\text { Between } \\
\text { measurements }\end{array}$ & 10344.067 & 2 & 5172.033 & \multirow[t]{2}{*}{949.49} & \multirow[t]{2}{*}{0.01} & \multirow[t]{2}{*}{$\begin{array}{l}0.970 \\
(97 \%)\end{array}$} \\
\hline & Error & 315.93 & 58 & 5.447 & & & \\
\hline
\end{tabular}

It is evident from the table that:

The "F" value was calculated. It was statistically significant at (0.001) level of the difference among the pre, post and follow-up 
administrations of the English Grammar Achievement test of the experimental group. The effect size was large which means that the variance among the pre, post and follow-up administrations of the English Grammar Achievement test of the experimental group in the whole levels and the total score of the English grammar achievement could be ascribed to the effectiveness of using Mind Maps.

\section{The effect of Using Electronic Mind Map on Improving English Grammar Achievement}

Blake and McGuigan modified gain ratio of the difference between the pre, post and follow-up administrations of the English Grammar Achievement test of the experimental group were calculated to determine the effect of using Mind Map on improving the first secondary stage students English Grammar Achievement as showing in the following table.

Table (7)

Blake and McGuigan modified gain ratio of the difference between the pre, post and follow-up administrations of the English Grammar Achievement test of the experimental group

\begin{tabular}{|c|c|c|c|c|c|c|c|c|}
\hline variable & $\begin{array}{c}\text { pre } \\
\text { test } \\
\text { Mean }\end{array}$ & $\begin{array}{c}\text { post } \\
\text { test } \\
\text { Mean }\end{array}$ & $\begin{array}{l}\text { Total } \\
\text { score }\end{array}$ & $\begin{array}{l}\text { Gain } \\
\text { score }\end{array}$ & $\begin{array}{c}\text { Blake } \\
\text { modified } \\
\text { gain } \\
\text { ratio } \\
\end{array}$ & Sig. & $\begin{array}{c}\text { McGuigan } \\
\text { modified } \\
\text { gain ratio } \\
\text { percentage } \\
\end{array}$ & Sig. \\
\hline $\begin{array}{l}\text { English } \\
\text { Grammar } \\
\text { Achievement } \\
\text { Test }\end{array}$ & 27.7 & 47.23 & 55 & 19.53 & 1.070 & $\begin{array}{c}\text { Accepted } \\
\text { between } \\
(1-2)\end{array}$ & $71.54 \%$ & $\begin{array}{c}\text { Accepted } \\
\leq 60 \%\end{array}$ \\
\hline variable & $\begin{array}{l}\text { post test } \\
\text { Mean }\end{array}$ & $\begin{array}{l}\text { follow } \\
\text { up } \\
\text { Mean }\end{array}$ & $\begin{array}{l}\text { Total } \\
\text { score }\end{array}$ & $\begin{array}{l}\text { Gain } \\
\text { score }\end{array}$ & $\begin{array}{c}\text { Blake } \\
\text { modified } \\
\text { gain ratio }\end{array}$ & Sig. & $\begin{array}{l}\text { McGuigan } \\
\text { modified gain } \\
\text { ratio } \\
\text { percentage } \\
\end{array}$ & Sig. \\
\hline $\begin{array}{l}\text { English } \\
\text { Grammar } \\
\text { Achievement } \\
\text { Test } \\
\end{array}$ & 47.23 & 52.67 & 55 & 5.44 & 1.099 & $\begin{array}{c}\text { Accepted } \\
\text { between } \\
(1-2)\end{array}$ & $70.01 \%$ & $\begin{array}{c}\text { Accepted } \\
\leq 60 \%\end{array}$ \\
\hline variable & $\begin{array}{l}\text { pre test } \\
\text { Mean }\end{array}$ & $\begin{array}{l}\text { follow } \\
\text { up test } \\
\text { Mean }\end{array}$ & $\begin{array}{l}\text { Total } \\
\text { score }\end{array}$ & $\begin{array}{l}\text { Gain } \\
\text { score }\end{array}$ & $\begin{array}{c}\text { Blake } \\
\text { modified } \\
\text { gain ratio }\end{array}$ & Sig. & $\begin{array}{c}\text { McGuigan } \\
\text { modified gain } \\
\text { ratio } \\
\text { percentage } \\
\end{array}$ & Sig. \\
\hline $\begin{array}{l}\text { English } \\
\text { Grammar } \\
\text { Achievement } \\
\text { Test }\end{array}$ & 27.7 & 52.67 & 55 & 24.97 & 1.369 & $\begin{array}{c}\text { Accepted } \\
\text { between } \\
(1-2)\end{array}$ & $91.47 \%$ & $\begin{array}{c}\text { Accepted } \\
\leq 60 \%\end{array}$ \\
\hline
\end{tabular}

It is evident from the table that using Mind Map improves the first secondary stage students English grammar achievement. 
To conclude, the interpretation of the hypothesis indicated that there is statistically significant difference between the mean score of the experimental group in the pre, post and follow up administrations of the English Grammar Achievement test (the cognitive levels and the total score) in favor of the post administration of the English Grammar Achievement test in comparison to the pre administration of the test and in favor of the follow-up administration of the English Grammar Achievement test in comparison to the post administration of the test. The" $F$ "value was statistically significant for all the cognitive levels measured and for the total score of the test. The effect size was large. Moreover, Blake and McGuigan modified gain ratio of the difference among the pre, post and follow up administrations of the English Grammar Achievement test of the experimental group accepted. This means that the Mind Mapping technique had substantially improved the experimental group's English grammar achievement. It is worth mentioning that, the previous results of the study are in line with those of Elkahlout (2013) and Abdallah (2015) as they stated that the use of Mind Maps increased the students' achievement and ability to learn English grammar language.

\section{Suggestions for Further Research} research:

The following points are recommended to be considered for further

1. Applying the experimental treatment to larger sample and to different stages of education.

2. Exploring the use of Mind Mapping technique in developing other English language skills.

3. Studying the effectiveness of applying electronic Mind Maps in enhancing students' English language skills achievement.

4. Conducting experimental research addressing the efficiency of Mind Mapping in developing the academic achievement of the students of special needs.

\section{References}

Abu Taleb, K, H. (2015). The Effectiveness of Pseudo Roles on Improving Grammar in Context for the Ninth Graders in the North Gaza Governorate. UnPublished M.A. Thesis, Al-Azhar University, Gaza.

Abu Allam,R. (2006). Research Methods in Psychological and Educational Sciences. Cairo: University Publishing House.

Aljaser, A. (2016). The Effectiveness of Electronic Mind Maps in Developing Academic Achievement and the Attitude Towards 
Learning English Among Primary School Students. International Education Studies; Published by Canadian Center of Science and Education. 10(12), 80-95.

Bekti, S., (2009). Teaching Reading Comprehension Using Mind Mapping Technique. Unpublished Master Thesis, University of Negeri Semarang. $\quad$ Retrieved September 2014 from http://lib.unnes.ac.id/1884/Boyson, G. (2009). The Use of the Mind Mapping in Teaching and Learning. The Learning Institute, 3.

Buehl, D. (2008). Clasroom Strategies for Interactive Learning. Third edition. International reading association.

Buzan, T. (1989). Use Both Sides of Your Brain, 3rd Ed. New York: Plume.

Buzan, T. (2000). The Mind Map Book. New York: Penguin Books.

Buzan, T. (2005). Mind map handbook. The Ultimate Thinking Tes, London: BBC Books.

Buzan, T. (2006). The Buzan Study Skills handbook the Short Cut to Success in your Studies. London: BBC.

Buzan, T. \& Buzan, B. (1996). The Mind Map Book: How to Use Radiant Thinking to Maximize Your Brain's Untapped Potential. New York: Plume.

Dara, C. (2010). Hand Drawing Vs. Using Software Mind Mapping. Retrieved From http://www.isoftwarereviews.com/hand-drawingvsusing-software-mind-mapping.

Davies, M. (2010). Concept mapping and argument mapping: What are the differences and do they matter? High Educe. Springer Science+ Business Media B.V.

Elabady, H. M., \& Jradat, Y. A. (2015). The impact of using e-Mind Maps in developing reading comprehension in English among ninth-year basic students. Jordan Journal of Educational Sciences, 11(4), 469480.

Gomaan (2015). The Effect of Using Mind Maps to learn English Title of the study: grammar to the Third Secondary class Students in Sabya. Umm Al-Qura university: Curriculum and Instruction Department.

Guilford, J. P. (1956). Fundamental Statistics in Psychology and Education (3rd ed.). New York: McGraw Hill.

Harbi, A. (2013). The Effect of Using the Mind Mapping Technique on the Mastery of Grammar among Tenth Graders in Gaza Governorates. Gaza: Al Azhar University. From http://www.alazhar.edu.ps/arabic/He/files/20103501.pdf. 
Harmer, J. (2001). The practice of English Language Teaching (3rd end). England: Pearson Education limited

Horton, P. B., McConney, A. A., Gallo, M., Woods, A. L., Senn. G. J., \& Hamelin, D. (1993). An investigation of the effectiveness of mind mapping as an instructional tool. Science Education, 77, 95-111.

Ibrahim, M.A.J. (2013). The Impact of Digital Mind Maps on Science Achievement among Sixth Grade Students in Saudi Arabia[J], Procedia - Social and Behavioral Sciences. 103, 1078 - 1087.

Krasnic, T. (2011). How to Study with Mind Maps: Concise Learning Method. Concise books publishing LLC.

Mento, A. J., Martinelli, P. \& Jones R. M. (1999). Mind Mapping in Executive Education: Applications and Outcomes. The Journal of Management Development, (18)4.

Mohaidat, M. (2018). The Impact of Electronic Mind Maps on Students' Reading Comprehension. Canadian Center of Science and Education, (11)4.

Nesbit, J. C., \& Adesope, O. O. (2006). Learning with Concept and Knowledge Maps: A meta-analysis. Review of Educational Research, 76(3), 413-448.

Obaid, O. (2010). The Effectiveness of Three Grammar Teaching Approaches on the Achievement of Secondary School Students. Unpublished Master Thesis, Faculty of Education: IUG, Gaza.

Ruffini, M. (2008). Using e-maps to organize and navigate online content. EDUCAUSE Quarterly, 31(1), 56-61.

Singh, R. (2011). Controversies in Teaching English Grammar. Academic Voices: A Multidisciplinary Journal, 1, 56-60.

Stephens, P. and Hermus, C. (2007). Making art connections with graphic organizers. School Arts: The Art Education Magazine for Teachers, (106), 8-55.

Thornbury, S. (2004). How to Teach Grammar?, England: Pearson Education.

Verghese, C. P. (1989). Teaching English as a Second Language. New Delhi: Sterling Publishers Pvt.Ltd. 